*ak RMIS View/Frint Document Cover Sheet tow

This document was retrieved from the Documentation and Records Manaqement (DRM) ISEARCH System. It is intended for Information only and may not be the most recent or updated version. Contact a Document Service Center (see Hanford Info for locations) if you need additional retrieval information.

Accession \#: D196093600

Document \#: SD-WM-IP-007

Title/Desc:

B PLANT TREATMENT \& STORAGE \& DISPOSAL UNITS INSPECTION PLAN

Pages: 28 
CORAPLTE

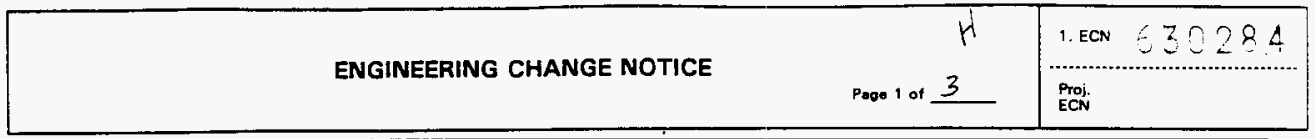

\begin{tabular}{|c|c|c|c|c|c|c|}
\hline \multirow{3}{*}{$\begin{array}{l}\text { 2. ECN Category } \\
\text { (mark one) } \\
\text { Supplemental } \\
\text { Oirect Revision } \\
\text { Change ECN } \\
\text { Temorrary } \\
\text { Standby } \\
\text { Supersedure } \\
\text { Cancel/Noid }\end{array}$} & \multirow{3}{*}{$\begin{array}{r}{[]} \\
{[\times]} \\
{[]} \\
{[]} \\
{[]} \\
{[]} \\
{[]}\end{array}$} & \multicolumn{2}{|c|}{$\begin{array}{l}\text { 3. Originator's Name, Organization, MSIN, } \\
\text { and Telephone No. } \\
\text { T. G. Beam, 16F00, S4-66, 372- } \\
\text { 0019 }\end{array}$} & 3a. USO R & ifred? & $\begin{array}{l}\text { 4. Date } \\
\text { April 25, } 1996\end{array}$ \\
\hline & & \multicolumn{2}{|c|}{$\begin{array}{l}\text { 5. Project Iitle/No./Work Order No. } \\
\text { B Plant Treatment, Storage, and } \\
\text { Disposal (TSD) Units Inspection } \\
\text { Plan }\end{array}$} & \multicolumn{2}{|c|}{$\begin{array}{l}\text { 6. Bldg./Sys./Fac. No. } \\
\text { B Plant/221B }\end{array}$} & $\begin{array}{c}\text { 7. Approval Designator } \\
E\end{array}$ \\
\hline & & \multicolumn{2}{|c|}{$\begin{array}{l}\text { 8. Document Numbers Changed by this ECN } \\
\text { (includes sheet no. and rev.) } \\
\text { WHC-.SD-WM-IP-007, Rev. } 0\end{array}$} & \multicolumn{2}{|c|}{$\begin{array}{l}\text { 9. Related ECN No(s). } \\
\text { None }\end{array}$} & $\begin{array}{l}\text { 10. Related Po No. } \\
\text { None }\end{array}$ \\
\hline \multicolumn{2}{|c|}{$\begin{array}{l}\text { 11a. Modification Work } \\
\text { [] Yes (fill out Blk. } \\
{[X] \text { No (NA Blks, 11b, }} \\
{[1 c, 11 d)}\end{array}$} & $\begin{array}{l}\text { 11b. Work Package } \\
\text { No. } \\
\text { N/A }\end{array}$ & \multicolumn{2}{|c|}{$\begin{array}{l}\text { 11c. Modification Work Complete } \\
\text { N/A } \\
\text { Cog. Engineer Signature \& Date }\end{array}$} & \multicolumn{2}{|c|}{$\begin{array}{l}\text { 11d. Restored to Original Condi- } \\
\text { tion (Temp. or Standby ECM only) } \\
\text { N/A }\end{array}$} \\
\hline
\end{tabular}

12. Description of Change

This revision is a complete rewrite of the inspection $p l a n$. It reflects current facility conditions, as well as the changing regulations. It removes significant detail from the plan which was committing B Plant to inspection efforts far in excess of that required by the regulations. Additional inspection checklists have been added to the document. No change bars are included in the revised document.

\begin{tabular}{|c|c|c|c|}
\hline Criteria Change & Design Improvement & Environmental & Facility Deactivation \\
\hline As-found & Facilitate Const & Const. Error/Onission & Design Error/Omission \\
\hline
\end{tabular}

13b. Justification Details

This change is necessary for the inspection plan to accurately reflect plan conditions and allow the facility to meet regulatory requirements.

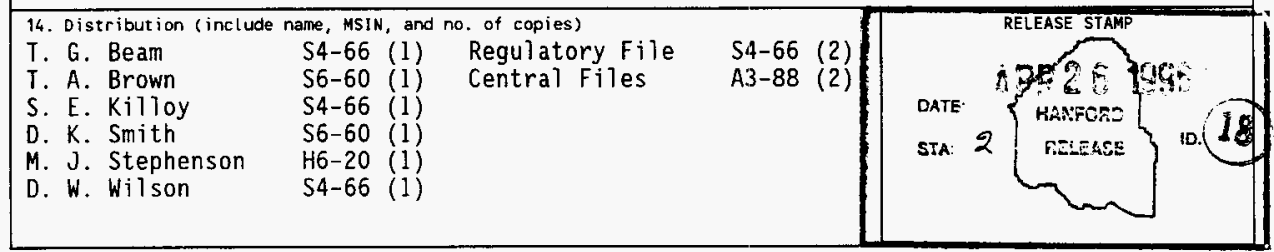




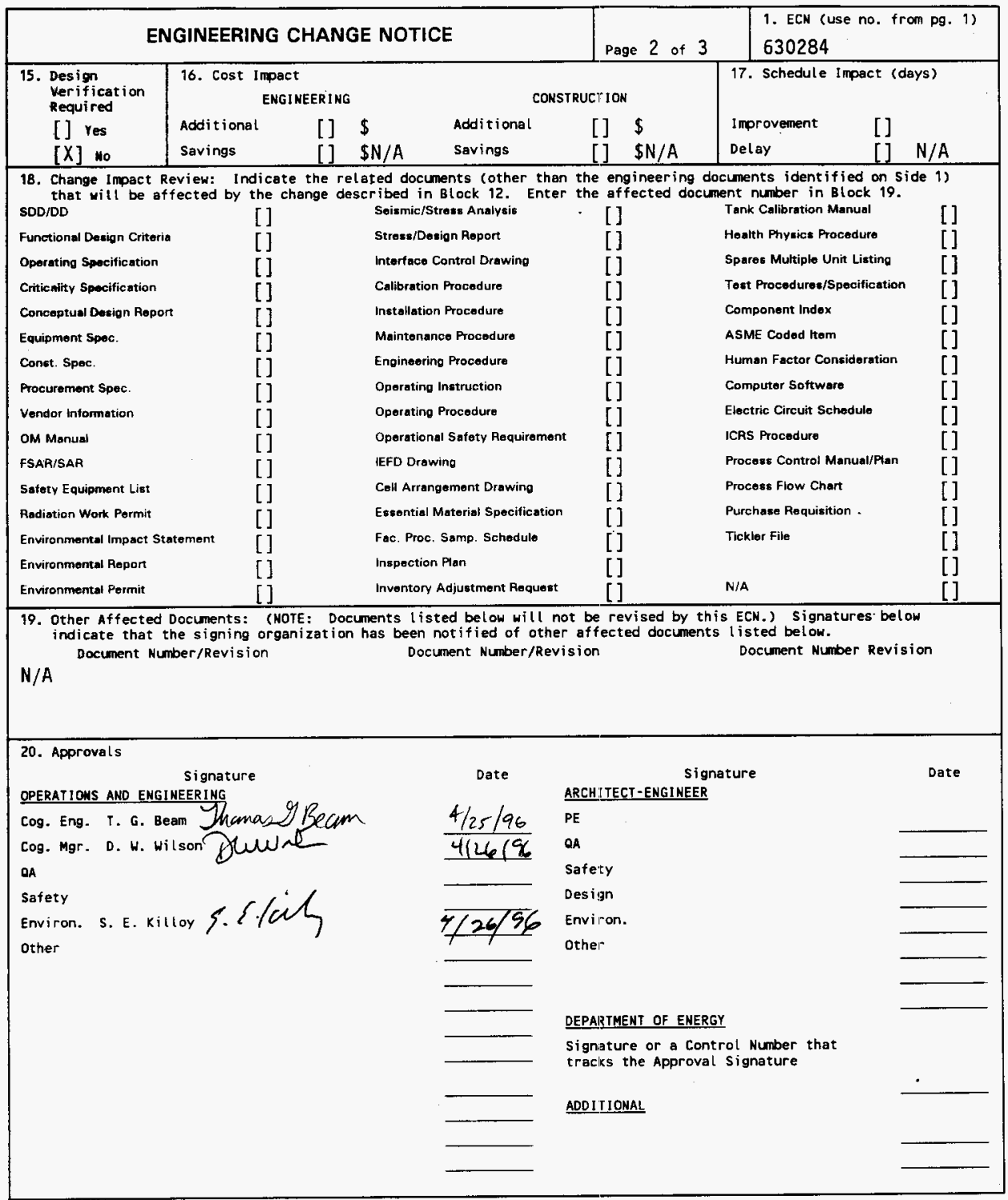




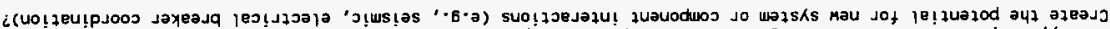

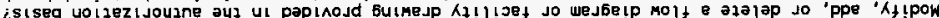

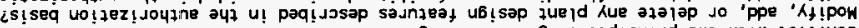

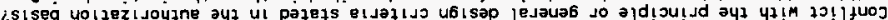

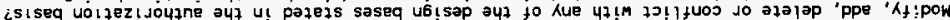
¿s!seq uo! $70 z$ ! Joyłne oył u! paq! Josəa

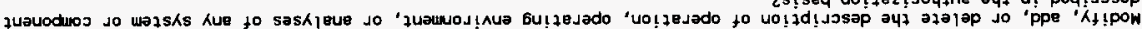

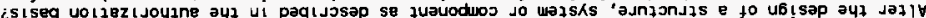

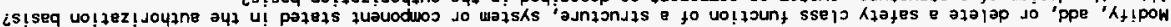

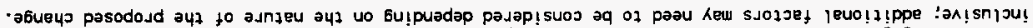

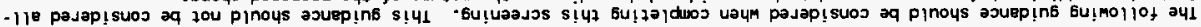

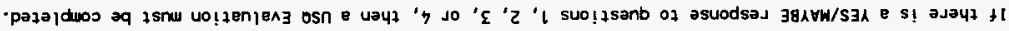
$96 / 56 / 4: 27 e 0$

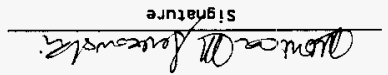

(aWRN fuțd)

$$
\overline{95 / 52 / 6} \text { :ә7е0 }
$$

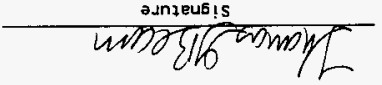

!YSMOYরAOS W W $W$ Z\# 30Sn

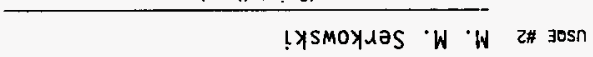

(כuen zU! Jd)

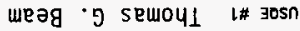

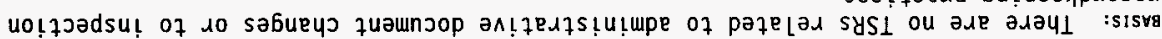

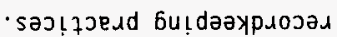

$$
\text { aqkew/sah }[] \text { ON }[\mathrm{X}] \text { V/N [] }
$$

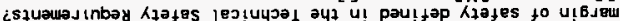

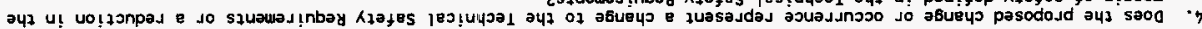

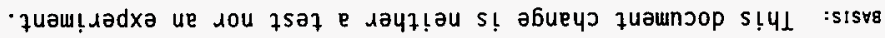$$
\text { aqkew/sok [] ON [] } \forall / N[X]
$$

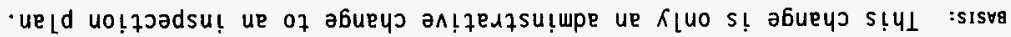

$$
\text { aqkew/sah [] ON }[] \text { } \forall / N[X]
$$

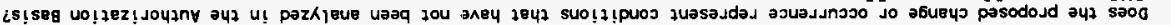

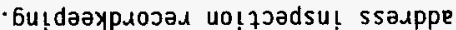

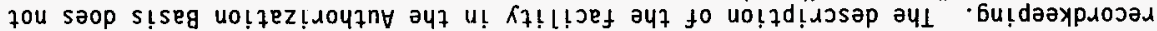

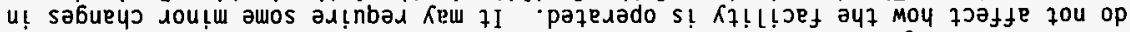

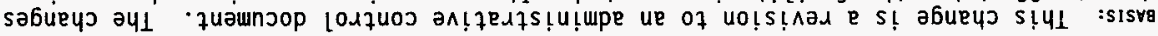

zqken/sal [] ON $[\mathrm{X}] \quad \forall / N[]$

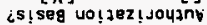

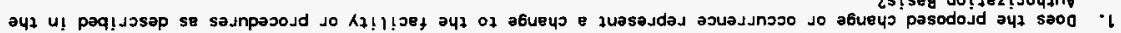

SHOI IS Jno

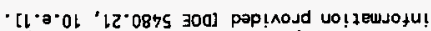

\begin{tabular}{|c|c|c|c|}
\hline$/$ to I abed & ONING:3YOS OSก & ので -96-d8 & : JaquinN Uo! 1EO!t!2uap! -1 \\
\hline
\end{tabular}

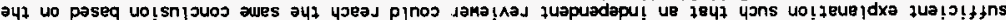

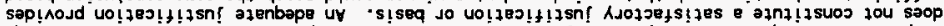

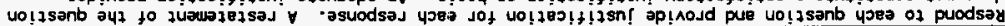

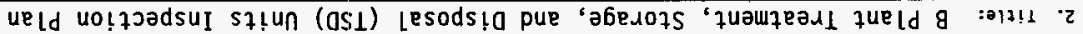




\section{B Plant Treatment, Storage, and Disposal (TSD) Units Inspection Plan}

Thomas G. Beam

Westinghouse Hanford Company, Richland, WA 99352

U.S. Department of Energy Contract DE-ACO6-87RL10930

$\begin{array}{llll}\text { EDT/ECN: } & \text { ECN } 630284 & \text { UC: } 630 & \\ \text { Org Code: } & 16 F 00 & \text { Charge Code: } & \text { KN43B } \\ \text { B\&R Code: } & \text { EW3135090 } & \text { Total Pages: } & 25\end{array}$

Key Words: B Plant, TSD, Inspection Plan, WAC 173-303, Tank Systems, Container Storage, Containment Building

Abstract: This inspection plan is written to meet the requirements of WAC 173-303 for operations of a TSD facility. Owners/operators of TSD facilities are required to inspection their facility and active waste management units to prevent and/or detect malfunctions, discharges and other conditions potentially hazardous to human health and the environment. A written plan detailing these inspection efforts must be maintained at the facility.

TRADEMARK DISCLAIMER, Reference herein to any specific conmercial product, process, or service by trade name, trademark, manufacturer, or otherwise, does not necessarily constitute or imply its endorsement, recommendation, or favoring by the United States Goverrment or any agency thereof or its contractors or subcontractors.

Printed in the United States of America. To obtain copies of this document, contact: HHC/BCS Document Control Services, P.O. Box 1970, Mailstop H6-08, Richland WA 99352, Phone (509) 372-2420; Fax (509) 376.4989.
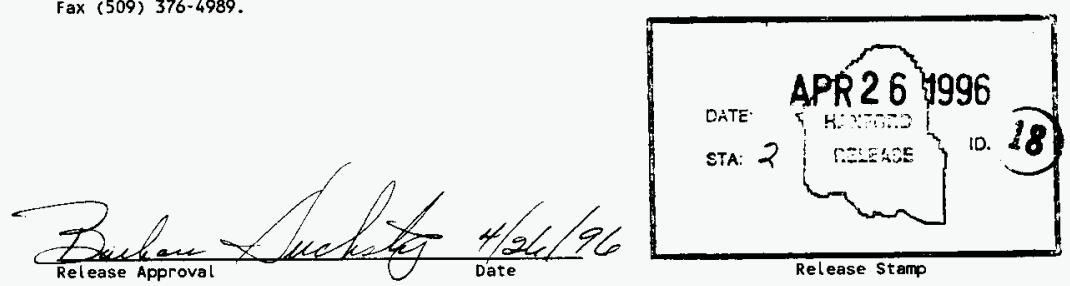

Approved for Public Release 
(2) Title

B Plant Treatment, Storage, and Disposal (TSD) Units Inspection Plan

CHANGE CONTROL RECORD

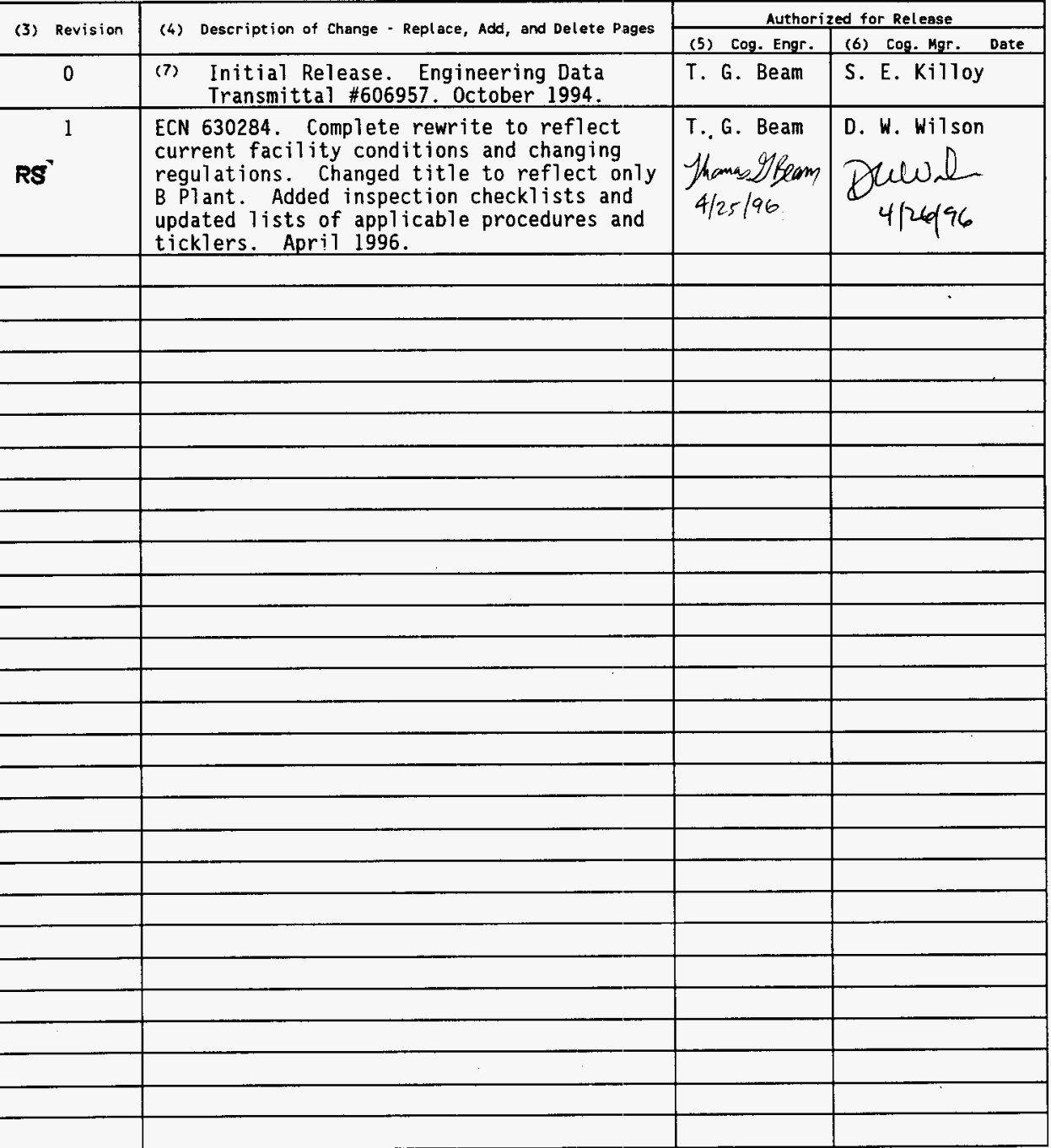


WHC-SD-WM-IP-007, Revision 1

B Plant Treatment, Storage, and Disposal (TSD) Units Inspection Plan

Fulfilling the requirements of WAC 173-303

B Plant/WESF Regulatory Compliance

Apri1 1996 
WHC-SD-WM-IP-007, REV. 1

SIGNATURE APPROVAL PAGE

PREPARED BY:

Thomas I. Beam

$4 / 16 / 96$

T. G. Beam, Engineer

Date

B Plant/WESF Regulatory Compliance

APPROVED BY:

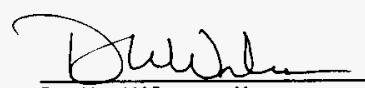

D.W. Wilson, Manager

B Plant/WESF Regulatory Compliance

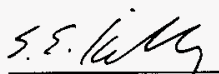

S. E. Killgy Environmental Compliance officer

B Ptant/WFSF Transition Project

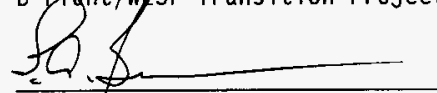

T. A. Brown, Manager

BCplant Operations

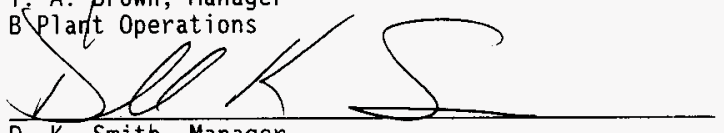

D. K. Smith, Manager

B Plant Facility

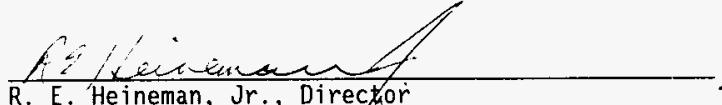

R. E. Heineman, Jr., Direct ar

B Plant/WESF Complex
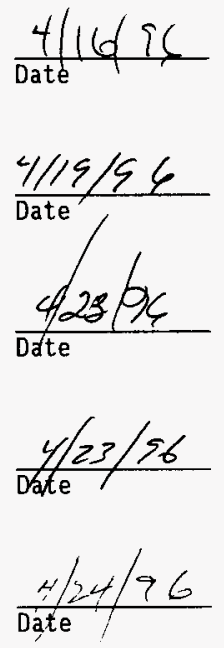

i i 


\section{TABLE OF CONTENTS}

1.0 INTRODUCTION . . . . . . . . . . . 1

1.1 B PLANT FACILITY DESCRIPTION . . . . . . . . . . . . . . 1

1.2 PROGRAM RESPONSIBILITIES ............... 2

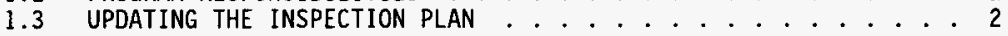

2.0 GENERAL INSPECTIONS .................. 3

2.1 GENERAL INSPECTION REQUIREMENTS ............. 3

2.2 B PLANT GENERAL INSPECTIONS .............. 3

2.2.1 Facility Surveillance ............. 4

2.2 .2 Communications Equipment .......... 4

2.2.3 Safety/Emergency Equipment . . . . . . . . . 4

2.2.4 Fire Protection Systems ........... . 5

2.2 .5 Security .............. . . 5

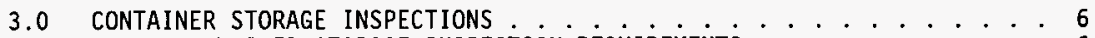

3.1 CONTAINER STORAGE INSPECTION REQUIREMENTS .......... 6

3.2 B PLANT CELL 4 CONTAINER STORAGE AREA . . . . . . . . . . 6

3.3 B PLANT CELL 4 INSPECTIONS ............... 6

4.0 TANK SYSTEM INSPECTIONS . . . . . . . . . . . . . . . 9

4.1 TANK SYSTEM INSPECTION REQUIREMENTS . . . . . . . . . . . . . 9

4.2 B PLANT TANK SYSTEM TSD UNITS ............... . . . . . .

4.2.1 Low Leve1 Waste Tank System . . . . . . . . . . . . 10

4.2.2 Organic Waste Tank System . . . . . . . . . . 10

4.2.3 Neutralized Current Acid Waste Tank System . . . . . . 10

4.2.4 Low Level Waste Concentrator Tank System . . . . . . . . 10

4.3 B PLANT TANK SYSTEM INSPECTIONS . . . . . . . . . . 10

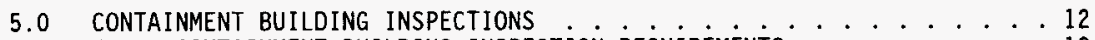

5.1 CONTAINMENT BUILDING INSPECTION REQUIREMENTS . . . . . . 12

5.2 B PLANT CANYON AND PROCESS CELLS $\ldots \ldots \ldots \ldots$

5.3 B PLANT CONTAINMENT BUILDING INSPECTIONS ......... 13

APPENDIX A: B PLANT OPERATIONS TICKLERS AND PROCEDURES USED TO MEET TSD FACILITY INSPECTION REQUIREMENTS ............. . . A-1

APPENDIX B: HANFORD FIRE DEPARTMENT AND FIRE SYSTEM MAINTENANCE INSPECTION/MAINTENANCE SCHEDULE FOR B PLANT . . . . . . . B- 1

\section{LIST OF FIGURES}

Figure 1. B Plant Cel1 4 Container Storage Inspection Checklist . . . 8

Figure 2. B Plant Containment Building Weekly Inspection Log Sheet. . 14 


\subsection{INTRODUCTION}

In accordance with Washington Administrative Code (WAC), Chapter 173-303, "Dangerous Waste Regulations" (WAC 173-303), a written inspection plan is required for the operation of a treatment, storage and disposal (TSD) facility and individual TSD units. B Plant is a permitted TSD facility currently operating under interim status with an approved Part A Permit. Various operational systems and locations within or under the control of B Plant have been permitted for waste management activities. Included are the following TSD units:

Cell 4 Container Storage Area
B Plant Containment Building
Low Level Waste Tank System
Organic Waste Tank System
Neutralized Current Acid Waste (NCAW) Tank System
Low Level Waste Concentrator Tank System

This inspection plan complies with the requirements of WAC 173-303. It addresses both general TSD facility and TSD unit-specific inspection requirements. Sections on each of the TSD units provide a brief description of the system configuration and the permitted waste management activity, a summary of the inspection requirements, and details on the activities B Plant uses to maintain compliance with those requirements.

\subsection{B PLANT FACILITY DESCRIPTION}

Since construction in 1943, B Plant has had several missions. Recovery of plutonium using a bismuth phosphate chemical separation process took place from 1945-1952. Modification for a second mission, cesium and strontium recovery and purification, occurred in the early 1960's.

Currently, B Plant is a facility transitioning to shutdown. Its sole mission is to support the safe management and storage of its residual radionuclide inventory, as we 17 as that of the Waste Encapsulation and Storage Facility (WESF). The primary operation of B Plant is waste management in its canyon and process cells. 


\subsection{PROGRAM RESPONSIBILITIES}

The ultimate responsibility for ensuring that B Plant has a compliant TSD inspection program rests with the B Plant Director and B Plant management. Responsibilities for specific portions of the program are shared as follows.

B Plant/WESF Regulatory Compliance has the responsibility to:

- Maintain knowledge of TSD inspection requirements applicable to $B$ Plant.

- Revise this inspection plan as necessary to reflect regulatory changes and current facility conditions.

- Assess the compliance status of the program on a periodic basis and ensure that any necessary corrective actions are performed.

B Plant Operations has the responsibility to:

- Perform the required surveillances and inspections as detailed in this plan.

- Maintain the appropriate surveillance/inspection documentation and records as required by this plan.

\subsection{UPDATING THE INSPECTION PLAN}

This plan will be revised as necessary to reflect changing regulations, facility conditions, and permitting documentation. The appendices will be reviewed/revised at least annually to maintain an up-to-date listing of the applicable facility operating procedures and inspection/surveillance activities. 
WHC-SD-WM-IP-007, REV. 1

\subsubsection{Facility Surveillance}

General surveillance of B Plant is performed in accordance with approved POPs. During each surveillance, B Plant personne? are instructed to look for any off-normal operating conditions. Unusual conditions and situations requiring maintenance attention are noted. Special fire watches and cold weather protection, if necessary, are handled as part of the general surveillance process.

During general surveillance, inspectors observe the Operator Interface Unit (OIU), which displays alarms and process conditions from the Facility Process Monitoring Control System (FPMCS). The FPMCS manages information relayed from monitoring equipment interfaced with facility process systems. All displays and readouts which are outside of established operating parameters are noted.

All observations and comments are recorded in the B Plant General Surveillance Log Book and on the appropriate procedure data sheets. Specific procedures and ticklers are 1 isted in Appendix $A$. All surveillance records used to maintain compliance with TSD inspection requirements are maintained at $B$ Plant for a minimum of five years from the date of the inspection.

\subsubsection{Communications Equipment}

$\mathrm{B} \mathrm{Pl}$ ant is equipped with internal communication systems to relay emergency or other information to facility personnel and the public. These systems include telephones, PAX phones, and various emergency alarms. Hand-held, two-way radios are also available for use when necessary.

Telephone and radio repairs are made by the appropriate onsite maintenance organization as needed. The PAX phone system is a public address system used at B Plant. Repairs and maintenance of the system are handled as deficiencies are noted. Routine functional testing of the PAX phone system is performed in accordance with the appropriate Operations Tickler.

Emergency alarms in use at B Plant include evacuation and take cover sirens, fire gongs, and crash alarm phones. The evacuation and take cover sirens, as well as the crash alarm phone are inspected and tested per the appropriate Operations Tickler. Testing of the fire gongs is the responsibility of the Hanford Fire Department.

\subsubsection{Safety/Emergency Equipment}

Safety and emergency equipment at B Plant is maintained and inspected through the use of the Operations Tickler system and preventative maintenance procedures. Equipment which is maintained and inspected in this manner include emergency lanterns, emergency acid suit lockers, self-contained breathing apparatus, portable eye washes, fixed eye washes and safety showers. This ensures that the equipment is in good condition, functional and available for use when needed. 
WHC-SD-WM-IP-007, REV. 1

\subsubsection{Fire Protection Systems}

Smoke detectors and manual pull boxes are located throughout B Plant, as are sprinkler and/or deluge systems. These systems have a direct tie to the Hanford Fire Department (HFD) and provide automatic notification when an alarm is actuated. Portable fire extinguishers and fire hose stations are located throughout B Plant, as are numerous fire doors and windows. Several fire hydrants are located in the vicinity of B Plant.

Fire systems and equipment are inspected and tested on a regular schedule as required in WHC-CM-4-41, Fire Protection Program Manual. The majority of inspections are the responsibility of HFD and Fire System Maintenance (FSM), which track these efforts using the fire equipment automated recall system (FEARS). Systems and equipment which are the responsibility of HFD and FSM include smoke detectors, manual pull boxes, the deluge and sprinkler systems, and fire hydrants. Through its operations Tickler and PM systems, B Plant provides maintenance and inspections for primary and secondary fire system valves, the emergency water supply system, and fire doors. B Plant shares responsibility for fires hoses and hose stations, and portable fire extinguishers with HFD and FSM.

Details on the inspection of fire protection systems specific to the B Plant canyon process cells permitted as individual TSD units are provided in the appropriate section of this plan for each TSD unit.

\subsubsection{Security}

The Hanford Site is a controlled access area. Around-the-clock surveillance and security is provided by Hanford patrol. Marned barricades are maintained at checkpoints on access roads leading to the Hanford Site. Vehicle operators wishing to enter the Hanford Site must possess and display a DOE-issued security badge at the checkpoints. This provides the security necessary to prevent the general public from exposure to the hazards associated with the $B$ Plant TSD facility.

B Plant is located in the 200 East Area of the Hanford Site. The perimeter of the 200 East Area is fenced. Openings in the fenced perimeter provide access for authorized vehicles and personnel. Signs are posted at B Plant which indicate the hazards present and state that only authorized personnel are allowed access. This provides the security necessary to prevent unauthorized Hanford personnel from exposure to the hazards associated with the B Plant TSD facility 
WHC-SD-WM-IP-007, REV. 1

\subsection{CONTAINER STORAGE INSPECTIONS}

This section provides a summary of the container storage inspection requirements for TSD units, a brief description of the B Plant container storage TSD unit, and details the efforts employed by B Plant to maintain compliance with these requirements.

\subsection{CONTAINER STORAGE INSPECTION REQUIREMENTS}

Regulations outlining the requirements for inspections of container storage TSD units are located in WAC 173-303-630, "Use and Management of Containers". In summary, these regulations require the owner/operator to perform the following action:

* At least week $1 y$, inspect areas where containers are stored, looking for leaking containers and for deterioration of containers and the containment system caused by corrosion, deterioration, or other factors.

In addition, the owner/operator must keep an inspection log including at least the date and time of the inspection, the printed name and the handwritten signature of the inspector, a notation of the observations made and the date and nature of any repairs or remedial actions taken. The log must be kept at the facility for at least five years from the date of the inspection.

\subsection{B PLANT CELL 4 CONTAINER STORAGE AREA}

The B Plant Cell 4 Container Storage Area is used to store mixed waste and radioactive low level waste. The waste is stored in 55-gallon drums, and is generated from routine operations in the Waste Encapsulation and Storage Facility (WESF) hot cells. Following packaging in the WESF $A$ Cell, the drums are transported to B Plant for storage in Cell 4 . The drums are stored in Cell 4 on racks which keep the drums elevated off of the concrete cell floor.

Cell 4 is a nonprocessing cell in the B Plant canyon facility that is $13 \mathrm{ft}$ $(3.96 \mathrm{~m})$ wide, $27 \mathrm{ft} 6 \mathrm{in} .(8.38 \mathrm{~m})$ long, and $28 \mathrm{ft}(8.5 \mathrm{~m})$ deep. Cell 4 is a completely enclosed cell when its $6-\mathrm{ft}-(1.8-\mathrm{m}-)$ thick concrete cover blocks are in place. These cover blocks protect the containers and greatly reduce the risk of container corrosion and deterioration, as well as shield the canyon from the higher levels of radiation present in the cells. The cover blocks must be removed remotely by crane to gain access to cell 4 . There are no means for a manned entry into the cell.

\subsection{B PLANT CELL 4 INSPECTIONS}

Because of access restrictions to Cell 4, visual inspections cannot be physically performed by personnel, but must be accomplished remotely using the canyon crane and a video camera. Operation of the crane exposes B Plant personnel to the elevated levels of radiation present in the canyon. Performing these video inspections of Cell 4 on a weekly basis, as required by 
WAC 173-303, would expose personnel to levels of radiation inconsistent with the As Low As Reasonably Achievable (ALARA) principle practiced on the Hanford Site.

B Plant performs inspections of the Cell 4 Container Storage Area whenever additional waste containers are added to the TSD unit. At a minimum, inspections will be completed once a year. The containers are inspected for breaches of containment, excess corrosion, and structural defects, and to ensure the lids are sealed. None of the drums stored in Cell contain liquids, so leaks are not a concern. The video will be viewed as the inspection is performed and may be recorded for future examination. The inspection results are documented using the Cell 4 Container Storage Inspection Checklist (Figure 1). Inspection records are maintained at B Plant for at least five years from the date of inspection.

$B P l a n t$ functionally tests the in-cell fire protection system per the appropriate Operations Tickler and POP (Appendix A). All other components of the fire protection system are inspected and maintained by the HFD and FSM (Appendix B) as outlined in section 2.2.4 of this plan. 
WHC-SD-WM-IP-007, REV. I

\section{B PLANT CELL 4 CONTAINER STORAGE INSPECTION CHECKLIST}

Video taped on:

1. Are any containers leaking? (If yes, explain below.) YES / N0

2. Do any containers have excessive corrosion?

(If yes, explain below.)

YES I NO

3. Do any containers have structural defects? (If yes, explain below.)

YES / NO

4. Do all containers have sealed lids? (If yes, explain below.)

YES / NO

COMMENTS/CORRECTIVE ACTIONS:

Inspector:

(print name)

Date:

Time:

(signature)

THIS CHECKLIST AND ASSOCIATED DOCUMENTATION MUST BE KEPT AT B PLANT FOR 5 YEARS IN ACCORDANCE WITH WAC 173-303-630(6).

Figure 1. Cell 4 Storage Container Inspection Checklist 


\subsection{TANK SYSTEM INSPECTIONS}

This section provides a summary of the tank system inspection requirements for TSD units, a brief description of the B Plant tank system TSD units, and details the efforts employed by B Plant to maintain compliance with these requirements.

\subsection{TANK SYSTEM INSPECTION REQUIREMENTS}

Regulations outlining the requirements for inspections of tank system TSD units are located in WAC 173-303-640 "Tank Systems". In summary, these regulations require the owner/operator to perform the following actions:

- Develop and follow a schedule and procedure for inspecting overfill controls;

* Inspect, at least once every operating day, the aboveground portions of each tank system to detect corrosion or leaks, the data gathered from monitoring any leak detection equipment to ensure that the tank system is being operated according to its design, and the construction materials and the area immediately surrounding the externally accessible portion of the tank system (including the secondary containment system) to detect erosion or signs of releases of dangerous waste; and

* Inspect cathodic protection systems, if present, to ensure that they are functioning properly.

The inspections must be documented in the operating record of the facility. The inspection $\mathrm{log}$ must include the time and date of the inspection, the printed name and handwritten signature of the inspector, a notation of the observations made and the date and nature of any repairs or remedial actions taken. The log must be kept at the facility for at least five years from the date of the inspection.

\subsection{B PLANT TANK SYSTEM TSD UNITS}

B Plant has permitted four different tank systems within its canyon process cells for storage and/or treatment of dangerous waste. Each of these systems consists of a number of process vessels (tanks, etc.) and associated ancillary piping and equipment. The four permitted TSD tank systems in B Plant are the low level waste system, the organic waste system, the neutralized current acid waste (NCAW) system and the low level waste concentrator (LLWC) system.

Each of the tank systems and their associated piping are located in various canyon process cells, which are completely enclosed when their concrete cover blocks are in place. These cover blocks protect the tanks and greatly reduce the risk of corrosion and deterioration, as well as shield the canyon from the higher levels of radiation present in the cells. The cover blocks must be 
WHC-SD-WM-IP-007, REV. 1

removed remotely by crane to gain access to the tank systems. There are no means for a manned entry into any of the cells.

\subsubsection{Low Level Waste Tank System}

The low level waste tank system is used to collect and hold low level liquid waste generated during operation of B Plant and WESF, prior to its transfer to the Double Shel1 Tank Farms. Chemical addition to meet Tank Farms waste acceptance criteria occurs in this tank system. The low level waste tank system consists of Tank 9-1 (Cel1 9, Tank \#1), Tank 10-1, Tank 24-1, Tank 25-1 and Tank 25-2, along with associated ancillary piping. These tanks are permitted for both storage and treatment of dangerous waste.

\subsubsection{Organic Waste Tank System}

The organic waste tank system is used to store organic mixed waste generated during past processing of Tank Farms waste at B Plant. The organic waste tank system consists of Tank 26-1, Tank 27-2, Tank 27-3, Tank 27-4, Tank 28-3, Tank 28-4, Tank 29-4 and Tank 30-3, along with associated ancillary piping. These tanks are permitted for storage of dangerous waste.

\subsubsection{Neutralized Current Acid Waste Tank System}

The neutralized current acid waste (NCAW) tank system was intended for use in processing of the NCAW as part of the Tank Waste Remediation pretreatment project. When this was cancelled, the NCAW inventory was transferred back to the Double Shell Tank Farms. This system is inactive and not being used to store or treat dangerous waste. There are no plans to utilize this system for waste management purposes in the future. The NCAW tank system consists of Tank 6-2, Tank 7-1, Tank 7-2, Tank 8-1, Tank 8-2, Tank 13-1, Tank 14-2, Tank 29-3, Tank 39-2 and Tank 39-5, along with associated ancillary piping. These tanks are permitted for storage and treatment of dangerous waste to reflect past operations.

\subsubsection{Low Leve1 Waste Concentrator Tank System}

The low level waste concentrator (LLWC) tank system was operated to concentrate the low level waste from the low level waste tank system. The LLWC is a therma? siphon and shel1 and tube heat exchanger located in Cell 23. This system is inactive and not being used to treat dangerous waste. The LLWC tank system consists of Waste Concentrator E-23-3, Deentrainer D-23-2, Tube Bundles E-23-3-2 and E-23-3-2, Condenser E-23-4 and Tank 23-1. This system is permitted for treatment of dangerous waste to reflect past operations.

\subsection{B PLANT TANK SYSTEM INSPECTIONS}

Because of access restrictions to the process cells and the tank systems contained within, visual inspections cannot be physically performed by personnel, but must be accomplished remotely using the canyon crane and a video camera. Operation of the crane exposes B Plant personnel to the 
WHC-SD-WM-IP-007, REV. I

elevated levels of radiation present in the canyon. Performing video inspections of the aboveground portions of the tank systems (including the associated ancillary piping) and the area immediately surrounding the external portion of the tanks on a daily basis, as required by WAC 173-303, would expose personnel to levels of radiation inconsistent with the As Low As Reasonably Achievable (ALARA) principle practiced on the Hanford Site.

B Plant inspects its dangerous waste tank systems on a daily basis by monitoring the liquid waste levels in the tanks through the use of remote instrumentation readings. This monitoring data is obtained during routine surveillance activities in accordance with approved plant operating procedures. B Plant only inspects those tanks which are currently operated or which contain liquid waste. Inactive or empty tanks are not inspected as part of the routine surveillance procedure. Tank moritoring instrumentation is maintained and calibrated on a routine basis using the CBRS system. Inspection records are maintained at $B$ Plant for at least five years from the date of inspection.

Monitoring the liquid levels in the active dangerous waste tanks on a daily basis allows B Plant to identify trends in tank levels which might indicate the presence of a leak or spill. Remote video equipment is used to inspect the process cells and tank systems when a leak or spill is suspected.

None of the B Plant dangerous waste tank systems are equipped with cathodic protection systems. All vessels are stainless steel.

B Plant functionally tests the in-cell fire protection system per the appropriate Operations Tickler and POP (Appendix A). All other components of the fire protection system are inspected and maintained by the HFD and FSM (Appendix B) as outlined in section 2.2.4 of this plan. 
WHC-SD-WM-IP-007, REV. I

\subsection{CONTAINMENT BUILDING INSPECTIONS}

This section provides a summary of the containment building inspection requirements for TSD units, a brief description of the $B$ Plant containment building TSD unit, and details the efforts employed by B Plant to maintain compliance with these requirements.

\subsection{CONTAINMENT BUILDING INSPECTION REQUIREMENTS}

Regulations outlining the requirements for inspections of containment building TSD units are located in 40 CFR 265, Subpart DD "Containment Buildings". In summary, these regulations require the owner/operator to perform the following actions:

* Develop and follow an inspection schedule and procedure that ensures maintenance of the structural integrity of the unit and prompt detection of any leaks or releases to the air, ground, or water; and

* Inspect, at least once every seven days, data gathered from monitoring equipment and leak detection equipment, as well as the containment building and the area surrounding the containment building to detect signs of releases of dangerous waste.

The inspections must be documented in the operating record of the facility. The inspection $\log$ must include the time and date of the inspection, the printed name and handwritten signature of the irispector, a notation of the observations made and the date and nature of any repairs or remedial actions taken. The log must be kept at the facility for at least five years from the date of the inspection.

\subsection{B PLANT CANYON AND PROCESS CELLS}

The B Plant canyon facility and process cells (221-B Building) are permitted as a containment building TSD unit. The 221-B Building is a reinforced concrete structure 259.1 meters ( 850 feet) long, 20.7 meters ( 68 feet) wide, and 22.5 meters (74 feet) high. A typical cell is 5.5 meters (18 feet) long, 3.9 meters (13 feet) wide, and 8.5 meters (28 feet) deep. The 221-B Building contains 40 such cells. Each cell has concrete cover blocks which serve as the cell ceiling. The tops of these cover blocks act as the canyon deck.

Solid mixed waste stored in the containment building consists primarily of failed process jumpers and equipment containing lead and/or residues of Flisted process wastes. No free liquids are stored in the containment building. The waste stored in the containment building is protected from the elements (wind, rain, etc.), is solid, and is not subject to moving or shifting. 


\subsection{B PLANT CONTAINMENT BUILDING INSPECTIONS}

Volume 57 of the Federal Register, page 37217 (57 FR 37217), dated August 18, 1992 , on the subject of containment building inspections, states that "...these weekly inspections need not be unduly burdensome. Electronic monitoring of liquid in secondary containment systems or of air pressure differentials between the inside and outside of a containment building are examples of relative cost-effective monitoring techniques."

In accordance with this guidance provided by the United States Environmental Protection Agency (EPA), B Plant inspects the B Plant Containment Building on a weekly basis by monitoring the canyon to atmosphere differential pressure as an indicator of potential loss of containment and integrity of the unit. This weekly inspection is performed using an approved Operations Tickler and data sheets from routine surveillance procedures (Appendix $A$ ) and utilizes the $B$ Plant Containment Building Weekly Inspection Log Sheet (Figure 2) to document the inspection. Inspection records are maintained at B Plant for at least five years from the date of inspection. 
WHC-SD-WM-IP-007, REV. 1

\section{B PLANT CONTAINNENT BUILDING WEEKLY INSPECTION LOG SHEET}

1. B Plant Canyon to Atmosphere Differential Pressure (PI-C-PV1, Area 1-D), (0.04 inches vacuum minimum) in. vac.

2. Has daily surveillance been performed per operating procedure, B0-040-001, section 5.1[4] (B Plant Canyon Exhaust System Surveillance, sheet 4 of 4 ), YES / NO within the past week? Circle correct answer.

3. Have there been any off-normal or unusual notations made on the past week's surveillance sheets which are related to an inability or difficulty in maintaining the required canyon to atmosphere differential pressure? Circle correct answer.

If so, provide explanation in the Comments section below.

COMMENTS/CORRECTIVE ACTIONS:

Inspector:

$\frac{\text { (print name) }}{\text { (signature) }}$

Date:

Time:

THIS LOG AND ASSOCIATED DOCUMENTATION MUST BE KEPT AT B PLANT FOR 5 YEARS IN ACCORDANCE WITH WAC 173-303-320 (2)(d).

Figure 2. B Plant Containment Building Weekly Inspection Log Sheet 
WHC-SD-WM-IP-007, REV. 1

\section{APPENDIX A}

B PLANT OPERATIONS TICKLERS AND PROCEDURES

USED TO MEET TSD FACILITY INSPECTION REQUIREMENTS

A-1 
WHC-SD-WM-IP-007, REV. I

\section{B PLANT OPERATIONS TICKLERS}

$\begin{array}{ll}\text { W-12 } & \text { Check Emergency Well Pumps } \\ \text { W-19 } & \text { Crash Alarm Test } \\ \text { W-45 } & \text { Inspection of SCBA's } \\ \text { W-50 } & \text { B Plant Containment Building Weekly Inspection } \\ \text { M-03 } & \text { Check Inside Canyon Door Locks and Stairwell Lights } \\ \text { M-07 } & \text { Inspect Outside Area Lights and Stairwell Doors } \\ \text { M-08 } & \text { Inspect Fire Extinguishers \& Hose Lines } \\ \text { M-13 } & \text { Inspection of Vent. Systems (Canyon, P.G. \& Op gal.) } \\ \text { M-19 } & \text { Check Acid Suit Lockers - B Plant } \\ \text { M-21 } & \text { Primary and Secondary Valve Check } \\ \text { M-23 } & \text { Siren Alarm and B Plnt/WEP Pax Systein Alarm Test } \\ \text { M-48 } & \text { Check Safety Showers/Eyewashes O B Plant } \\ \text { S-07 } & \text { Change Out Port. Eye Wash Saline Sol. in Elec. Gallery } \\ \text { A-02 } & \text { Inspection of Out Buildings Around B Plant/WESF }\end{array}$

W-weekly tickler

M-monthly tickler

S-semiannual tickler

A-annual tickler 


\section{PREVENTATIVE MAINTENANCE PROCEDURES (PM)}

PM 2B15001

PM 2B22009

PM 2B22017

PM 2B22038

BO-020-005

BO-020-021

$\mathrm{BO}-020-025$

BO-040-001

BO- $040-002$

BO- $140-002$

B0-140-005
Fire Door Inspection-B Plant/WESF

Emergency Lantern Inspection

B Plant Emergency Light Electrical Inspection

Emergency Lantern Annual Test

PLANT OPERATING PROCEDURES (POP)

Remove Cell Blocks and Perform Cell Work

Inspect and Test Fire Protection Water System

Store WESF Waste Drums in Cell 4

Ventilation System Surveillance

Perform General Surveillance

Test Fire Protection in 291-B

Test Emergency Water Well Pumps 
WHC-SD-WM-IP-007, REV. 1

\section{APPENDIX B}

HANFORD FIRE DEPARTMENT AND FIRE SYSTEM MAINTENANCE

INSPECTION/MAINTENANCE SCHEDULE FOR B PLANT

B-1 


\section{FIRE INSPECTION/MAINTENANCE ACTIVITY (FREQUENCY)}

\section{Control Panels}

1. Verify that all panel lamps and light emitting diodes have the capability to light and to provide the correct indications. (annually)

2. Verify that circuit interface properly transmits alarm signals to the computer-aided dispatch system. (every 4 months)

3. Functional test audible and visible trouble signals. (annually)

4. Functional test zone disconnect or isolating switches. (annually)

Input Devices

5. Inspect smoke detectors. (every 6 months)

6. Functional test each smoke detector. (annually)

7. Sensitivity test each smoke detector. (every 2 years)

8. Inspect and functional test all flame, fire and gas detectors. (every 6 months)

9. Operational test water flow alarms. (every 4 months)

10. Operational test the extinguishing systems alarm initiation switch. (every 6 months)

11. Operational test manual stations/pull boxes. (annually)

12. Operational test supervisory signal initiating devices. (annually)

13. Operational test post indicator valve. (annualiy)

\section{Emergency Power}

14. Inspect lead acid batteries for fire protection emergency power. (varies depending on need)

\section{Output Devices}

15. Operational test alarm indicating appliances. (annually for supervised devices, bimonthly for unsupervised devices)

16. Operational test all annunciators. (annually)

17. Functional test all automatic initiation circuits. (annually)

18. Audible sound check fire bells/gongs. (monthly)

\section{B-2}


WHC-SD-WM-IP-007, REV. 1

\section{Sprinkler Systems}

19. Flow test main drains. (every 4 months)

20. Inspect al1 gages. (monthly)

21. Inspect internal condition of piping. (every 10 years)

22. Clean and inspect strainers and nozzles. (annually)

23. Functional test deluge and preaction systems. (annually)

24. Inspect low-expansion systems. (every 6 months)

25. Inspect fire hoses and hose stations. (anrually)

26. Functional test fire hoses. (every 3 years)

27. Inspect fire department connections. (every 4 months)

28. Inspect fire hydrants. (every 4 or 6 months for various components)

29. Flush/drain test fire hydrants. (annually)

30. Flow test fire main hydrant. (annually)

Barriers and Doors

31. Inspect, repair and operational test fire doors. (every 6 months) 